\title{
Optimization of Modelling of storage conditions in forced Air cooling of SAPOTA (MANILKARAZAPOTA) using Response Surface Methodology
}

\author{
R. Renu ${ }^{1}$, Dr Kavita Waghray ${ }^{2} \& D r$ P Dinesh Sankar Reddy ${ }^{3,4}$ \\ 1- Ph.D. Research Scholar, JNTU, College of Engineering Ananthapuramu,renu.pillai96@gmail.com \\ 2- Professor, University College of Technology, Osmania University, kavitagl@ rediffmail.com \\ 3- Associate Professor ,JNTU, College of Engineering Ananthapuramu, \\ 4- Associate Professor, NIT Andhra Pradesh, pdsreddy@gmail.com
}

\begin{abstract}
Field heat can cause rapid deterioration of horticultural crops and therefore it is desirable to remove this heat as quickly as possible after harvesting, and the faster the deteriorative processes are retarded. The goal of the present study was to apply Response surface methodology (RSM) to search for the best conditions of Forced Air-Cooling system for extending the shelf life of Sapota. The parameters which affect the cooling rate the most were identified as Cooling Medium temperature $\left(4^{\circ} \mathrm{C}, 8^{\circ} \mathrm{C}\right.$ and $\left.25^{\circ} \mathrm{C}\right)$, Fruit Size $(0.00454 \mathrm{~m}, \quad 0.00567 \mathrm{~m}$ and $0.00662 \mathrm{~m})$ and Cooling Air Velocity $(0.5 \mathrm{~m} / \mathrm{s}, 1.5 \mathrm{~m} / \mathrm{s}$ and $2.5 \mathrm{~m} / \mathrm{s})$ at which the produce is stored. Based on general factorial design of RSM shelf life (number of days) as a response, $27\left(3^{3}\right)$ treatments were conducted. Optimum storage conditions for maximizing the shelf life were identified as Cooling Medium temperature $\left(4^{\circ} \mathrm{C}\right)$, Fruit Size $(40-50 \mathrm{~mm})$ and Cooling Air Velocity $(2.5 \mathrm{~m} / \mathrm{s})$. Under this optimum condition, the predicted shelf life of the stored Sapota and the experimental results gave close values of less than $1.03 \%$. The number of days of shelf life extended for Sapota is 28 days. Physio-chemical properties and microbial quality of stored Sapota was also evaluated. Percentage Loss in Weight was found to be maximum for control sample $(13 \%)$ whereas minimum for the cooled sample (0.04-0.123\%). TSS increased about $5 \%-7 \%$ for control but whereas for cooled sapota it was not more than $1-2 \%$.
\end{abstract}

Key words: Forced- Air Cooling, Response surface methodology (RSM), General factorial design.

\section{INTRODUCTION}

Reduction in field heat of horticultural produce is a main criterion in improving product quality, Shelf Life and physiological breakdown and Forced Air Cooling is a technique to achieve it. Forced Air Cooling is a technique of forcing cold air through product or packaging material [11,13]. Rapid cooling and ease of use are the advantages of Forced Air Cooling [2].Rapid Cooling of the produce is essential without causing Chilling injury [12].Variation in product quality can occur because of Non - uniform cooling [4]. The cooling rate of horticultural produce depends on their size, shape and thermal properties, airflow rate, cooling temperature and accessibility of the cooling air to the produce $[3,9,10]$.Physiological breakdown and Physical Injury can be reduced by cooling [1].It was stated that cooling time can be reduced by increasing Air Velocity which increases cooling rate and heat transfer fluxes across the apple [5]. The same observation was confirmed where optimum cold air velocity could decrease cooling time of food products [7]. Optimization of Forced Air-cooling technique for Oranges stacked on a pallet was done by using computational fluid dynamics. It was concluded that design of cooling system and packaging material is also important in increasing cooling rate and reduced system energy [10]. The optimum temperature for storage of Sapota(Manilkarazapota) 20 or $0^{\circ} \mathrm{C}$ for fruit at the turning or ripe stages [8]. The present study was done to evaluate and optimize the storage conditions of Sapota in Forced Air Cooling based on Shelf life and Physio - Chemical properties.

\section{MATERIALS AND METHODS}

\subsection{Forced Air Cooler Working}

The cooler was designed for storage of fruits. Cooler consists of a chamber with a Fan fitted on one side and multiple trays (made of thermocol) where the fruits were placed. Air is used as cooling media. During the testing period the thermocouple was inserted into Sapota fruit to know the variation of temperature in the fruit. The Air Velocity temperature were measured using Anemometer and digital thermometer respectively. The Air Velocity was changed by changing the speed of the Fan.Sapota were procured from local farm, cleaned; graded (according to size) and placed in the cabinet trays. The cabinet was tested for its suitability to reduce the temperature. The air medium temperature within the chamber was change by changing the coolant temperature. 
R. Renu et al., International Journal of Emerging Trends in Engineering Research, 9(6), June 2021, 669 - 674

\subsection{Percentage loss in Weight:}

Product weight was determined by digital weighing balance. The weight loss was measured using the following formula.

$$
\begin{gathered}
\text { Percentage loss in weight }(\text { PLW })= \\
\frac{\text { Initial weight }- \text { Final weight }}{\text { Initial weight }} \times 100
\end{gathered}
$$

\subsection{Total soluble solids}

The TSS content of the fruits was determined using the hand refractometer. A drop of fruit juice was placed onto the plate surface of the refractometer and the reading is taken directly as ${ }^{0}$ Brix.

\subsection{Statistical Analysis using General Factorial Design}

Three different set of treatments were applied to study the shelf-life extension of Sapota by Forced Air Cooling. The experiments were performed according to a full factorial design using design expert (8.0.4). The experiments are $3^{3}$ factorial design i.e. 27 treatment combinations for each set of treatments.

Total Treatments : 27

Design : Response Surface

Methodology (RSM).

\subsection{Total Plate Count Method:}

The nutrient agar medium was prepared by dissolving agar powder in distilled water according to formulation requirement. The sample was prepared by mixing solution of $5 \mathrm{gms}$ of sapota pulp in $45 \mathrm{~m} 1$ of distilled water. Under the sterilized conditions the analysis was conducted by adding 1 $\mathrm{ml}$ of sample in a petri plate and then agar media was poured into it. After solidifying the petri plates were kept in incubator for $24 \mathrm{hrs}$ at $30 \pm 1^{\circ} \mathrm{C}$. After $24 \mathrm{hrs}$ the total plate count was done by using colony counter and results were noted.

\section{RESULTS:}

\subsection{Time-Temperature relation}

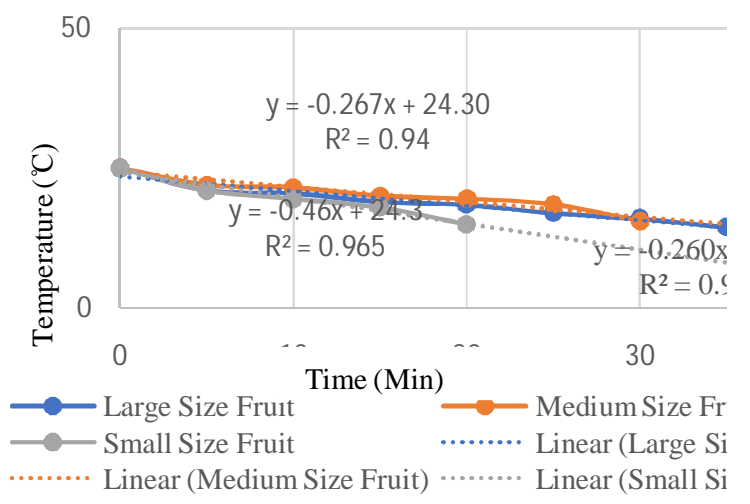

Figure 1: Time -Temperature Response of different sized Sapota at $2.5 \mathrm{~ms}^{-1}$
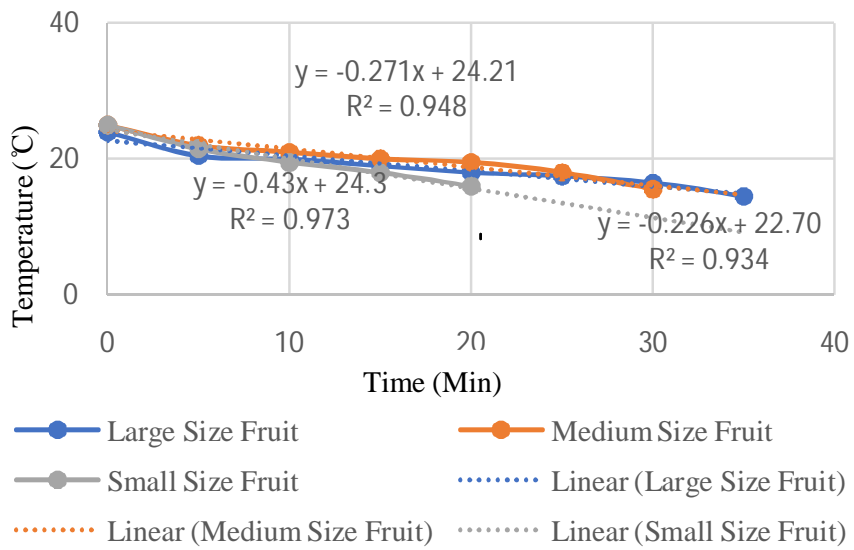

Figure 2:Time -Temperature Response of different sized Sapota at $1.5 \mathrm{~ms}^{-1}$

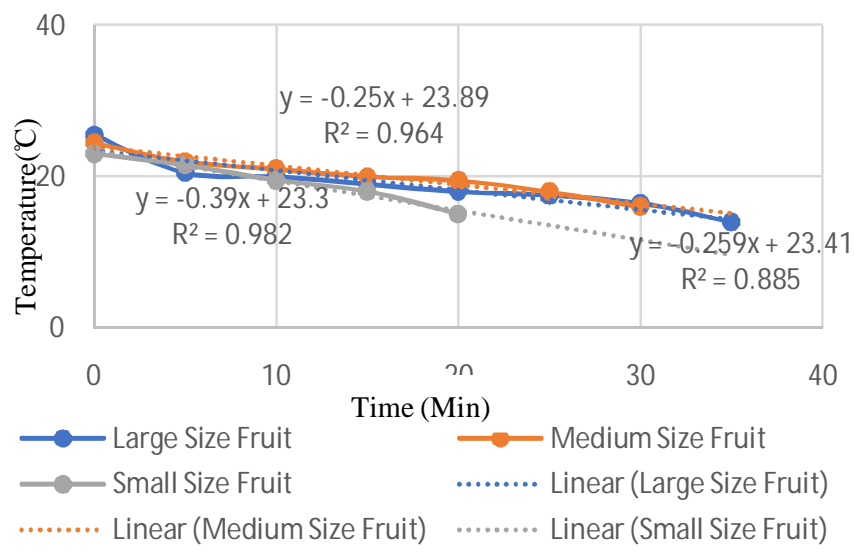

Figure 3:Time -Temperature Response of different sized Sapota at $0.5 \mathrm{~ms}^{-1}$

The above figures (Fig 1-3) demonstrate the relationship between time and temperature of fruits which were divided into three sizes at three different Air Velocity. Linear trend was observed at all the velocities and $\mathrm{R}^{2}$ value was the highest for small size fruit in all the cases.

\subsection{Percentage loss in Weight:}

The Percentage loss in Weight (PLW) at $4^{\circ} \mathrm{C}$ was significantly reduced by Forced Air Cooling as shown in Table1 and it was affected by Fruit size and Air Velocity for control sample (without cooling) was as high as $13.0 \%$. The Loss in weight was least at $1.5(\mathrm{~m} / \mathrm{s})$ Air Velocity similar observation was made by [3].

Table 1: Percentage Loss in Weight of Sapota Stored at different Air Velocities.

\begin{tabular}{|l|c|c|}
\hline $\begin{array}{l}\text { Fruit } \\
\text { Size }\end{array}$ & $\begin{array}{l}\text { Air } \\
\text { Velocity } \\
(\mathbf{m} / \mathbf{s})\end{array}$ & $\begin{array}{l}\text { PLW (\%) After 20 } \\
\text { Days of storage) }\end{array}$ \\
\hline Large & 0.5 & $0.123 \mathrm{bc}$ \\
\hline & 1.5 & $0.04 \mathrm{a}$ \\
\hline & 2.5 & $0.114 \mathrm{bc}$ \\
\hline Medium & 0.5 & $0.119 \mathrm{bc}$ \\
\hline & 1.5 & $0.052 \mathrm{e}$ \\
\hline & 2.5 & $0.100 \mathrm{c}$ \\
\hline
\end{tabular}




\begin{tabular}{|l|c|c|}
\hline Small & 0.5 & $0.087 \mathrm{~cd}$ \\
\hline & 1.5 & $0.062 \mathrm{de}$ \\
\hline & 2.5 & $0.080 \mathrm{cde}$ \\
\hline
\end{tabular}

* Means followed by the same letters are not significant but different letters are significant at 0.05 level according to L.S.D method.

\subsection{Total soluble solids}

The TSS content of fruits gradually increased throughout the storage period as shown in Table 2 but it was on par at lowest temperature.TSS content increase during ripening process in Sapota fruit can be related to production of more sugars in the fruit due to hydrolysis of starch and slight decline at overripe stage was due to utilization of sugars during respiration process.

Table 2: Change in TSS of Sapota at different

\begin{tabular}{|c|c|c|c|}
\hline $\begin{array}{c}\text { Fruit } \\
\text { Size }\end{array}$ & $\begin{array}{c}\text { Temp- } \\
\text { erature } \\
\text { ( C) }\end{array}$ & \multicolumn{2}{|c|}{ TSS $(\circ \mathbf{B})$} \\
\hline & & Before & $\begin{array}{c}\text { After 20 } \\
\text { Days of } \\
\text { Storage }\end{array}$ \\
\hline Large & 4 & $11 \pm 0.26$ & $12.5 \pm 0.21$ \\
\hline & 10 & $11.4 \pm 0.35$ & $12.9 \pm 0.35$ \\
\hline & 25 & $10.4 \pm 0.31$ & - \\
\hline Medium & 4 & $13 \pm 0.26$ & $13.0 \pm 0.33$ \\
\hline & 10 & $13.4 \pm 0.23$ & $13.6 \pm 0.32$ \\
\hline & 25 & $13.9 \pm 0.13$ & - \\
\hline Small & 4 & $12.5 \pm 0.29$ & $12.6 \pm 0.12$ \\
\hline & 10 & $12.0 \pm 0.23$ & $12.7 \pm 0.19$ \\
\hline & 25 & $12.5 \pm 0.22$ & - \\
\hline
\end{tabular}

-Indicates that fruit was decayed for the prescribed storage time period.The Values are indicated as mean \pm S.D of three fruit samples.

\subsection{Response Surface Method}

Details about the experimental runs, Medium temperature, Fruit Size and Air Velocityare tabulated. As the above-mentioned factors are controlling the cooling rate which in turn the shelf life of the produce Response Surface method was applied using Software by taking Shelf life as the Dependent Variable.

Table 3: Shelf life of Stored Sapota as a function of Medium temperature, Fruit Size and Air Velocity during Forced Air Cooling

\begin{tabular}{|l|c|l|l|c|}
\hline Run & $\begin{array}{l}\text { A: } \\
\text { Medium } \\
\text { temp }\left({ }^{\circ} \mathbf{C}\right)\end{array}$ & $\begin{array}{l}\text { B: } \\
\text { Fruit } \\
\text { Size } \\
(\mathbf{m})\end{array}$ & $\begin{array}{l}\text { C: Air } \\
\text { Velocity } \\
(\mathbf{m} / \mathbf{s})\end{array}$ & $\begin{array}{l}\text { shelf } \\
\text { life } \\
(\text { Days })\end{array}$ \\
\hline 1 & 4 & 0.00454 & 0.5 & 27 \\
\hline 2 & 4 & 0.00454 & 2.5 & 28 \\
\hline 3 & 4 & 0.00662 & 2.5 & 23 \\
\hline 4 & 4 & 0.00662 & 0.5 & 20 \\
\hline 5 & 25 & 0.00662 & 2.5 & 5 \\
\hline 6 & 10 & 0.00454 & 1.5 & 16 \\
\hline 7 & 4 & 0.00567 & 2.5 & 26 \\
\hline
\end{tabular}

\begin{tabular}{|l|c|c|c|c|}
\hline 8 & 10 & 0.00567 & 1.5 & 11 \\
\hline 9 & 4 & 0.00567 & 0.5 & 24 \\
\hline 10 & 10 & 0.00454 & 0.5 & 12 \\
\hline 11 & 25 & 0.00454 & 0.5 & 8 \\
\hline 12 & 25 & 0.00567 & 1.5 & 6 \\
\hline 13 & 25 & 0.00567 & 2.5 & 8 \\
\hline 14 & 4 & 0.00662 & 1.5 & 22 \\
\hline 15 & 4 & 0.00454 & 1.5 & 27 \\
\hline 16 & 10 & 0.00662 & 2.5 & 10 \\
\hline 17 & 25 & 0.00662 & 1.5 & 4 \\
\hline 18 & 25 & 0.00567 & 0.5 & 6 \\
\hline 19 & 25 & 0.00454 & 1.5 & 9 \\
\hline 20 & 25 & 0.00662 & 0.5 & 4 \\
\hline 21 & 10 & 0.00662 & 0.5 & 9 \\
\hline 22 & 4 & 0.00567 & 1.5 & 25 \\
\hline 23 & 10 & 0.00567 & 2.5 & 13 \\
\hline 24 & 25 & 0.00454 & 2.5 & 9 \\
\hline 25 & 10 & 0.00567 & 0.5 & 10 \\
\hline 26 & 10 & 0.00662 & 1.5 & 9 \\
\hline 27 & 10 & 0.00454 & 2.5 & 18 \\
\hline & & & & \\
\hline
\end{tabular}

\subsubsection{Model Fitting and Analysis of Response}

Good storage conditions should be able to maximize the shelf life of the produce. Table 3 presents the summary of the results for fitting a model. A model should be rejected if the result showed significance in the LOF test suggested by [6]. The Model F-value of 91.83 implies the model is significant. There is onlya $0.01 \%$ chance that a "Model F-Value" this large could occur due to noise.Values of "Prob > F" less than 0.0500 indicate model terms are significant. In this case A, $\mathrm{B}, \mathrm{C}$ are significant model terms (as shown in Table 4).Values of "Prob > F" less than 0.0500 indicate model terms are significant. In this case A, $\mathrm{B}, \mathrm{C}$ are significant model terms.

Table 4:Results Summary of Fitting a Model in the Optimization of Storage Conditions.

\begin{tabular}{|c|c|c|c|c|c|c|}
\hline $\begin{array}{l}\text { Sourc } \\
\text { e }\end{array}$ & $\begin{array}{l}\text { Sum } \\
\text { of } \\
\text { Squa } \\
\text { res }\end{array}$ & d & $\begin{array}{l}\text { Mea } \\
\text { n } \\
\text { Squa } \\
\text { re }\end{array}$ & $\begin{array}{l}\text { F } \\
\text { Val } \\
\text { ue }\end{array}$ & $\begin{array}{l}\text { p- } \\
\text { valu } \\
\text { e } \\
\text { Pro } \\
\text { b > } \\
\text { F }\end{array}$ & $\begin{array}{l}\text { Signific } \\
\text { ant/ } \\
\text { Non- } \\
\text { Signific } \\
\text { ant }\end{array}$ \\
\hline $\begin{array}{l}\text { Mode } \\
1\end{array}$ & $\begin{array}{c}1714 . \\
22\end{array}$ & $\begin{array}{l}1 \\
8\end{array}$ & 95.23 & $\begin{array}{c}91.8 \\
3\end{array}$ & $\begin{array}{c}< \\
0.00 \\
01\end{array}$ & $\begin{array}{c}\text { Significa } \\
\text { nt }\end{array}$ \\
\hline $\begin{array}{l}\text { A: } \\
\text { Medi } \\
\text { um } \\
\text { temp } \\
\left({ }^{\circ} \mathrm{C}\right)\end{array}$ & $\begin{array}{c}1554 . \\
30\end{array}$ & 2 & $\begin{array}{c}777.1 \\
5\end{array}$ & $\begin{array}{c}749 . \\
39\end{array}$ & $\begin{array}{c}< \\
0.00 \\
01\end{array}$ & $\begin{array}{c}\text { Significa } \\
\mathrm{nt}\end{array}$ \\
\hline $\begin{array}{l}\text { B: } \\
\text { Fruit } \\
\text { Size }\end{array}$ & $\begin{array}{c}128.0 \\
7\end{array}$ & 2 & 64.04 & $\begin{array}{c}61.7 \\
5\end{array}$ & $\begin{array}{c}< \\
0.00 \\
01\end{array}$ & $\begin{array}{c}\text { Significa } \\
n t\end{array}$ \\
\hline
\end{tabular}


R. Renu et al., International Journal of Emerging Trends in Engineering Research, 9(6), June 2021, 669 - 674

\begin{tabular}{|l|l|l|l|c|c|l|}
\hline$(\mathrm{m})$ & & & & & & \\
\hline $\begin{array}{l}\text { C: Air } \\
\text { Veloc } \\
\text { ity } \\
(\mathrm{m} / \mathrm{s})\end{array}$ & 22.30 & 2 & 11.15 & $\begin{array}{c}10.7 \\
5\end{array}$ & $\begin{array}{c}0.00 \\
54\end{array}$ & \\
\hline $\mathrm{AB}$ & 4.81 & 4 & 1.20 & 1.16 & 0.39 & \\
& & & & & 58 & \\
\hline $\mathrm{AC}$ & 3.26 & 4 & 0.81 & 0.79 & 0.56 & \\
& & & & & 54 & \\
\hline $\mathrm{BC}$ & 1.48 & 4 & 0.37 & 0.36 & $\begin{array}{c}0.83 \\
24\end{array}$ & \\
\hline
\end{tabular}

\begin{tabular}{|l|l|l|l|}
\hline Std Dev & 1.02 & R-Squared & 0.9952 \\
\hline Mean & 14.41 & Adj R-Squared & 0.9843 \\
\hline C.V \% & 7.07 & Pred R-Squared & 0.9451 \\
\hline PRESS & 94.50 & Adeq Precision & 23.485 \\
\hline
\end{tabular}

The "Pred R-Squared" of 0.9451 is in reasonable agreement with the "Adj R-Squared" of0.9843."Adeq Precision" measures the signal to noise ratio.A ratio greater than 4 isdesirable. Aratio of 28.485 indicates an adequate signal. This model can be used tonavigate the designspace. The best storage condition for Sapota as indicated by the model was smallest fruit size $(0.00454 \mathrm{~m})$, least temperature $\left(4^{\circ} \mathrm{C}\right)$ and highest Air velocity (2.5 $\mathrm{m} / \mathrm{s}$ ) as shown in Table 5 .

The suggested model was (in Terms of Coded Factors)

$\begin{array}{cr}\text { Shelf Life } & \\ +14.41 & * \mathrm{~A}[1] \\ +10.26 & * \mathrm{~A}[2] \\ -2.41 & * \mathrm{~B}[1] \\ +2.70 & * \mathrm{~B}[2] \\ -0.074 & * \mathrm{C}[1] \\ -1.07 & * \mathrm{C}[2] \\ -0.074 & * \mathrm{~A}[1] \mathrm{B}[1] \\ -0.037 & * \mathrm{~A}[2] \mathrm{B}[1] \\ +0.63 & * \mathrm{~A}[1] \mathrm{B}[2] \\ +0.41 & * \mathrm{~A}[2] \mathrm{B}[2] \\ -0.59 & * \mathrm{~A}[1] \mathrm{C}[1] \\ +0.074 & * \mathrm{~A}[2] \mathrm{C}[1] \\ -0.59 & * \mathrm{~A}[1] \mathrm{C}[2] \\ +0.074 & * \mathrm{~A}[2] \mathrm{C}[2] \\ +0.074 & * \mathrm{~B}[1] \mathrm{C}[1] \\ -0.37 & * \mathrm{~B}[2] \mathrm{C}[1] \\ +0.074 & * \mathrm{~B}[1] \mathrm{C}[2] \\ +0.30 & * \mathrm{~B}[2] \mathrm{C}[2] \\ -0.26 & \end{array}$

Table 5: Solutions for 27 combinations of categoric factor levels

\begin{tabular}{|c|c|c|c|c|c|}
\hline $\begin{array}{c}\text { Medi } \\
\text { um } \\
\text { Temp. }\end{array}$ & $\begin{array}{c}\text { Sample } \\
\text { Size }\end{array}$ & $\begin{array}{c}\text { Air } \\
\text { Veloci } \\
\text { ty }\end{array}$ & $\begin{array}{c}\text { Shelf } \\
\text { Life }\end{array}$ & $\begin{array}{c}\text { Desirabi } \\
\text { lity }\end{array}$ & $\begin{array}{c}\text { Model } \\
\text { Selection }\end{array}$ \\
\hline$\underline{4}$ & $\underline{0.00454}$ & $\underline{2.5}$ & $\underline{28.4074}$ & $\underline{1.000}$ & $\underline{\text { Selected }}$ \\
\hline 2 & 0.00454 & 1.5 & 27.6296 & 0.985 & \\
\hline 3 & 0.00567 & 2.5 & 26.1852 & 0.924 & \\
\hline
\end{tabular}

\begin{tabular}{|c|c|c|c|c|l|}
\hline 4 & 0.00454 & 0.5 & 25.963 & 0.915 & \\
\hline 5 & 0.00567 & 1.5 & 24.7407 & 0.864 & \\
\hline 6 & 0.00567 & 0.5 & 24.0741 & 0.836 & \\
\hline 7 & 0.0062 & 2.5 & 22.4074 & 0.767 & \\
\hline 8 & 0.0062 & 1.5 & 21.6296 & 0.735 & \\
\hline 9 & 0.0062 & 0.5 & 20.963 & 0.707 & \\
\hline 10 & 0.00454 & 2.5 & 17.0741 & 0.545 & \\
\hline 11 & 0.00454 & 1.5 & 15.6296 & 0.485 & \\
\hline 12 & 0.00454 & 0.5 & 13.2963 & 0.387 & \\
\hline 13 & 0.00567 & 2.5 & 13.1852 & 0.383 & \\
\hline 14 & 0.00567 & 1.5 & 11.0741 & 0.295 & \\
\hline 15 & 0.0062 & 2.5 & 10.7407 & 0.281 & \\
\hline 16 & 0.00567 & 0.5 & 9.74074 & 0.239 & \\
\hline 17 & 0.00454 & 2.5 & 9.51852 & 0.230 & \\
\hline 18 & 0.0062 & 1.5 & 9.2963 & 0.221 & \\
\hline 19 & 0.00454 & 1.5 & 8.74074 & 0.198 & \\
\hline 20 & 0.0062 & 0.5 & 7.96296 & 0.165 & \\
\hline 21 & 0.00454 & 0.5 & 7.74074 & 0.156 & \\
\hline 22 & 0.00567 & 2.5 & 7.62963 & 0.151 & \\
\hline 23 & 0.00567 & 0.5 & 6.18519 & 0.091 & \\
\hline 24 & 0.00567 & 1.5 & 6.18519 & 0.091 & \\
\hline 25 & 0.0062 & 2.5 & 4.85185 & 0.035 & \\
\hline 26 & 0.0062 & 0.5 & 4.07407 & 0.003 & \\
\hline 27 & 0.0062 & 1.5 & 4.07407 & 0.003 & \\
\hline & & & & & \\
\hline
\end{tabular}

\subsubsection{Diagnostic and Optimum Storage} conditions

Fig. 4 shows the relationship between the Medium Temperature and Shelf Life for Different Sized Fruits at velocity $2.5 \mathrm{~m} / \mathrm{s}$ in normal plot and Fig. 5 shows the relationship between the Medium Temperature, Shelf Life for Different Sized Fruits at highest Air Velocity $(2.5 \mathrm{~m} / \mathrm{s})$ in $3-\mathrm{D}$ plot. The highest value of shelf life (28 Days) could be observed at Medium temperature $4{ }^{\circ} \mathrm{C}$ for Small sized Sapota Fruit $(0.00454 \mathrm{~m})$ at highest Air Velocity $(2.5 \mathrm{~m} / \mathrm{s})$. The optimum Storage Temperature was found to be $4^{\circ} \mathrm{C}$, at an Air velocity of $2.5 \mathrm{~m} / \mathrm{s}$ for the smallest size Sapota i.e. $0.00454 \mathrm{~m}$.

\subsection{Microbial load of bell peppers stored in three different treatments}

Table 6: Microbial load of Sapota before and after 20

\begin{tabular}{|c|c|c|c|c|c|}
\hline \multicolumn{2}{|c|}{$\begin{array}{c}\text { At }{ }^{\circ} \mathrm{C} \\
(\mathrm{cfu} / \mathrm{ml})\end{array}$} & \multicolumn{2}{|c|}{$\begin{array}{c}\text { At 10 } \\
(\mathrm{cfu} / \mathrm{C} l\end{array}$} & \multicolumn{2}{c|}{$\begin{array}{c}\text { At } 25^{\circ} \mathrm{C} \\
(\mathrm{cfu} / \mathrm{ml})\end{array}$} \\
\hline Before & After & Before & After & Before & After \\
& & & & & \\
\hline $3.0 \mathrm{x}$ & $3.9 \mathrm{x}$ & $3.1 \mathrm{x}$ & $\begin{array}{c}4.8 \mathrm{x} \\
10^{-4}\end{array}$ & $\begin{array}{c}3.0 \mathrm{x} \\
10^{-4}\end{array}$ & - \\
$10^{-4}$ & $10^{-4}$ & $10^{-4}$ & $10^{\circ}$ & \\
\hline
\end{tabular}

- Indicates sample has been observed for Fungal Growth.

Microbial load after 20 days of fruit storage was evaluated using Total Plate Count. As shown in 
Table 6 at lowest temperature $\left(4^{\circ} \mathrm{C}\right)$ microbial spoilage was within acceptable range but at highest temperature $\left(25^{\circ} \mathrm{C}\right)$ fungal growth was observed within 4-9 days of Storage.

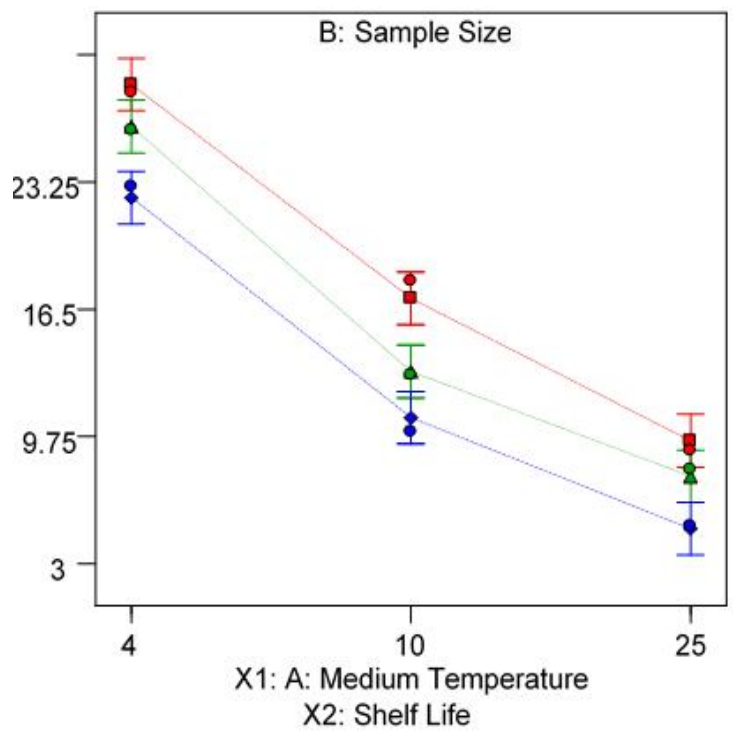

Figure 4:Relationship Between Medium Temperature, Shelf Life for Different Sized Fruits

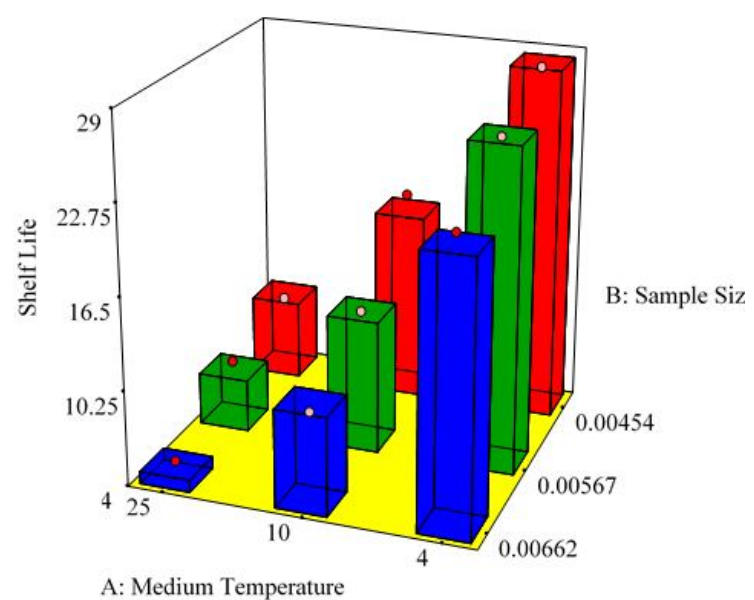

Figure 5: Relationship Between Medium Temperature, Shelf Life for Different Sized Fruits at Highest Air Velocity

\section{CONCLUSION}

In the present study the shelf life of Sapota was extended up to 28 days when stored under optimum storage conditions in Forced Air-Cooling Chamber. The most optimum conditions were found to be $4^{\circ}$ C, $2.5 \mathrm{~m} / \mathrm{sec}$ velocity for the smallest sized sapota among 27 treatments. As the Storage temperature and size of the fruit increased shelf-life decreased whereas as Air Velocity increased shelf life increased. Mathematical Modelling showed the relation between Air Velocity, Storage temperature and sample weight taken and the response (shelf life) and the best treatment combination as significant. Percentage Loss in Weight of the fruit sample was found to be maximum for control sample (without cooling) $13 \%$ after 4days of storage whereas minimum for the cooled sample 0.04-0.123\% after 10-20 days of storage period. TSS increased about $5 \%-7 \%$ for control but whereas for cooled sapota it was not more than 1$2 \%$. The microbial load of the best treatment combination was also within the permissible limits. Based on the results from this study, it can be concluded that Forced Air Cooling can be a more flexible, less expensive and simpler way for extending the shelf life of Sapota.

\section{REFERENCES}

1. Domingo Martinez-Romero, Salvador Castillo, Daniel Valero. Forced-air cooling applied before fruit handling to prevent mechanical damage of plums (Prunus salicina Lindl.). Postharvest Biology and Technology; 2003. 28: 135-142. PII: S09205 -5214 (02) 00142-4.

2. Edmond, J.P., Mercier, F., Sadfa, S.O., Bourre, M., Gakwaya, A. Study of parameters affecting cooling rate and temperature distribution in forced-air precooling of strawberry. 1996.

3. Elansari \& Mostafa. Vertical forced air pre-cooling of orange fruits on bin: Effect of fruit size, air direction, and air velocity. Journal of the Saudi Society of Agricultural Sciences; 2018. https://doi.org/10.1016/j.jssas.2018.06.006

4. Ferrua, M.J., Singh, R.P. Design guidelines for the forced-air cooling process of strawberries. International Journal of Refrigeration; 2009. 32, Pages 1932-

1943.https://doi.org/10.1016/j.ijrefrig.200 9.07.011.

5. Han, J., BadIa-melis, R., Yang, X., RuizGarcia, L., Qian, J., Zhao, C. CFD simulation of airflow and heat transfer during forced-air pre-cooling of apples. Journal of Food Process Engineering; 2017. $40 \quad$ (2), $1-11$. https://doi.org/10.1111/jfpe.12390

6. Meir, S; Rosenberger,I; Aharon, Z;Shoshana Grinberg, Fallik, E. Improvement of the postharvest keeping quality and colour development of Bell Pepper (cv. 'Maor') by packaging with polyethylene bags at a reduced temperature.Postharvest Biology and Technology; 1995.5:303-309.

7. Nalbandi, H., Sadegh, S., Hamid, R.G., Faramarz, R. Innovative Parallel Airflow System for forced-air cooling of strawberries. Food and Bioproducts 
R. Renu et al., International Journal of Emerging Trends in Engineering Research, 9(6), June 2021, $669-674$

Processing; 2016. Volume 100, pp. 440449.

https://doi.org/10.1016/j.fbp.2016.09.002

8. Snowdon, A.L. A Color Atlas of Postharvest Diseases of Fruits and Vegetables: General Introduction and Fruits; 1990. vol. 1. CRC Press, Boca Raton, FL.

9. Thijs Defraeye, Rutger Lambrecht , Mulugeta Admasu Delele, Alemayehu Ambaw Tsige ,Thompson, J.F., Mitchell, F.G., Rumsey, T.R., Kasmire, R.F., Crisosto, C.H.. Commercial cooling of fruits, vegetables, and flowers. Division of Agricultural and Natural Trans; 1998. ASAE 39, 2185-2191.

10. Thijs Defraeye, Rutger Lambrecht, Mulugeta Admasu Delele, Alemayehu Ambaw Tsige, Umezuruike Linus Opara , Paul Cronje, Pieter Verboven, Bart Nicolai . Forced convective cooling of citrus fruit: Cooling conditions and energy consumption in relation to package design. Journal of Food Engineering; 2014. 121 :118-127.

http://dx.doi.org/10.1016/j.jfoodeng.2013. 08.021

11. Thompson, J.F., Mitchell, F.G., Rumsey, T.R., Kasmire, R.F., Crisosto, C.H. Commercial cooling of fruits, vegetables, and flowers. Division of Agricultural and Natural Resources, University of California (Publication 21567); 1998.

12. Valente, M., Chamberel, A., Cordonnier, J., Pumborios, M. Finite element modelling of heat transfer in avocados. International Journal of Agro physics; 1996. 10, 123-129.

13. Yuping Gao, Shuangquan Shao, Shen Tian,Hongbo $\mathrm{Xu}$, Changqing Tian . Energy consumption analysis of the forced-air cooling process with alternating ventilation mode for fresh horticultural produce. Energy Procedia; 2017.142:2642-2647.

10.1016/j.egypro.2017.12.205. 